\title{
THREE GRASS MOTHS (LEPIDOPTERA: CRAMBIDAE) NEW TO THE FAUNA OF CROATIA
}

\section{Toni Koren \& Mladen Zadravec}

Hyla Association, Lipovac I 7, HR-10000 Zagreb, Croatia (e-mail: toni.koren@hhdhyla.hr)

Koren, T. \& Zadravec, M.: Three grass moths (Lepidoptera: Crambidae) new to the fauna of Croatia. Nat. Croat., Vol. 27, No. 1, 239-242, 2018, Zagreb.

During faunistic surveys of the moths of Croatia, three species of Crambidae were recorded for the first time in the country. Ostrinia quadripunctalis, a rare thermophilic species, has been found on Krč Hill, in the vicinity of Zagreb. Two migratory species, Spoladea recurvalis and Herpetogramma licarsisalis, have been found in the southern part of Croatia, on the island of Lokrum, near Dubrovnik.

Key words: Ostrinia quadripunctalis, Spoladea recurvalis, Herpetogramma licarsisalis, fauna, Island Lokrum, Dalmatia, new records, Croatia, Crambidae

Koren, T. \& Zadravec, M.: Tri vrste moljaca trava (Lepidoptera: Crambidae) nove za faunu Hrvatske. Nat. Croat., Vol. 27, No. 1, 239-242, 2018, Zagreb.

Tijekom faunističkih istraživanja Hrvatske tri pripadnika porodice Crambidae zabilježena su po prvi puta za Hrvatsku. Ostrinia quadripunctalis, rijetka termofilna vrsta, zabilježena je na području Krča u blizini Zagreba. Dvije migratorne vrste Spoladea recurvalis i Herpetogramma licarsisalis zabilježene su u južnom dijelu Hrvatske, na otoku Lokrumu.

Ključne riječi: Ostrinia quadripunctalis, Spoladea recurvalis, Herpetogramma licarsisalis, fauna, otok Lokrum, Dalmacija, novi nalaz, Hrvatska, Crambidae

Crambidae are one of the larger Microlepidoptera families, with more than 10,000 described species worldwide, while in Europe the family comprises approximately 430 species (DE JoNG et al., 2014), with many species being only occasional visitors to Europe, arriving from the tropics and neotropics (SLAMKA, 2008). The members of this family are small- to medium-sized moths, usually inhabiting grasslands or agricultural habitats.

In general, the micro moth fauna of eastern European countries is still not sufficiently known, which holds true both for this family and for Croatia. In neighbouring Slovenia 168 species have been recorded, according to the last checklist (LeSAR \& Govedič, 2010), and in Serbia 146 (JAKŠIĆ, 2016). As there is still no checklist for Croatia, the most comprehensive data sources is the Pyraloidea of Europe book series (SlamKA, 2006, 2008, 2013) and Fauna Europaea (DE Jong et al., 2014). Additionally, historical literature and the occasional newly published faunistic work (e.g. HABELER, 2008) are a valuable source for the country.

During the last few years, field trips were carried out across Croatia in order to survey the moth fauna of the country, and this included many previously unvisited areas and regions. Moths were surveyed using pyramidal UV light traps, with two to five traps used per locality. They were in operation usually for 4 hours after dusk. The specimens 
collected were set, identified, and stored in the private collection of the first author (Koren, Zagreb). For identification of species we used Slamka (2006, 2008, 2013). For each species, the exact locality, coordinates, date and additional notes are provided.

\section{Ostrinia quadripunctalis (Denis \& Schiffermüller, 1775)}

Material examined: Croatia, Zagreb, Krč hill, 27.5.2016, N: 45,902019, E: 16,086892, 335 m a.s.l., 1 ex., obs. \& coll. Mladen Zadravec

Note: In Europe this species (Fig. 1) is present in central and eastern European countries, Norway, Italy and the southern Balkans (SlamKA, 2013). It is regarded as highly local, rare and endangered, in need of the strictest protection in Europe (LERAUT, 2012; Slamka, 2013). It inhabits xerophilous, open habitats. Exactly on such a habitat, one specimen of this rare species was recorded during the moth fauna survey of $\mathrm{Krč}$ Hill, near Zagreb. The area of Krč is one of the last remaining thermophilous slopes in northern Croatia and is also included in the Natura 2000 Ecological Network (HR2001298 Vejalnica i Krč) and lies also within the borders of the Significant landscape Goranec (Anonymous, 2015a, 2015b). This is the first record of this species in Croatia.

\section{Herpetogramma licarsisalis (Walker, 1859)}

Material examined: Croatia, Lokrum Island, botanical garden, 26.10.2016, N: 42,625264, E: 18,121176, 18 m a.s.l., 7 ex., obs. \& coll. Toni Koren.

Note: This species (Fig. 2) is native to the tropics and subtropics. It is usually found on grasslands and agricultural habitats. It has been recorded in several European countries, including Portugal, Spain, Malta, Italy, Greece, Cyprus, and even in the United Kingdom and Sweden (Slamka, 2013). We recorded this species on Lokrum, where seven specimens were collected within the Forest Vegetation Special Reserve. The botanical garden holds many foreign plant species, and is surrounded on one side by a forest, and an olive grove on the other. This is the first record of the species in Croatia.

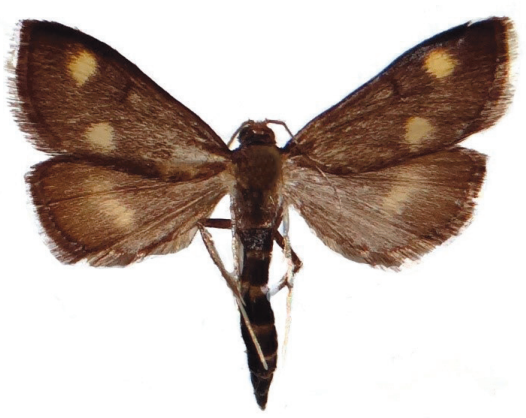

Fig. 1. Ostrinia quadripunctalis from Krč, near Zagreb Fig. 2. Herpetogramma licarsisalis from Lokrum (photo by T. Koren).

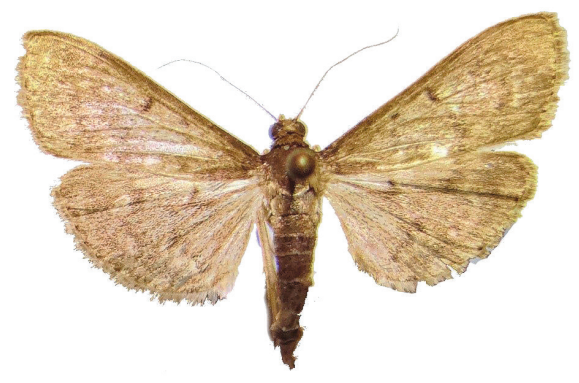

Island (photo by T. Koren). 


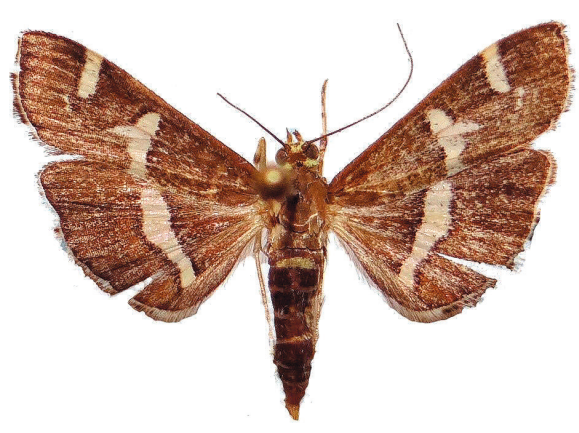

Fig. 3. Spoladea recurvalis from Lokrum island (photo by T. Koren).

Spoladea recurvalis (Fabricius, 1775)

Material examined: Croatia, Island Lokrum, botanical garden, 26.10.2016, $\mathrm{N}: 42,625264, \mathrm{E}: 18,121176,18 \mathrm{~m}$ a.s.1., 2 ex., obs. \& coll. Toni Koren, det. F. Slamka.

Note: This species (Fig. 3.) is native to the tropics and subtropics, and it is possibly resident in southern Europe (SLAMKA, 2013). It is usually present in gardens and agricultural landscapes. So far it has been recorded from the westernmost Mediterranean countries and in some northern countries as a migratory species (SlamkA, 2013). Recently it was also recorded in Slovenia (JEž et al., 2015). This species has been recorded in Croatia on Lošinj Island in 2015 (Gомвос \& Koren, unpublished), so the record from Lokrum Island is the second record for Croatia, and the first published observation of this species in the country. Presumably, it can be found also on other Adriatic islands and coastal areas.

With further surveys, especially of the southern and montane areas of Croatia, further records of new and interesting Crambidae species are to be expected. Also, the new species record from Krč Hill, located only several kilometres from Zagreb, indicates the need of further visits and surveys of similar habitats in northern Croatia. However, it is usually very difficult to put any species record into perspective, due to the lack of systematic overviews, checklists and even complete identification guides. Even so, such small faunistic contributions represent significant steps in exploring the diverse fauna of Croatia.

\section{ACKNOWLEDGMENTS}

The authors are grateful to the Public Institution Rezervat Lokrum and to the City of Dubrovnik for the financial support for the surveys of Lokrum Island. Our gratitude goes also to František Slamka for help with the identification of Herpetogramma licarsisalis.

Received February 7, 2018

\section{REFERENCES}

AnOnYmous, 2015a: Natura 2000 Standard Data Form. HR2001298 Vejalnica i Krč.

Anonymous, 2015b: EUNIS -Site factsheet for Goranec [WWW Document]. URL http://eunis.eea.europa. $\mathrm{eu} /$ sites/377900 (accessed 29.9.2015).

de Jong, Y., Verbeek, M., Michelsen, V., Bjørn, P. de P., los, W., Steeman, F., Bailly, N., Basire, C., Chylarecki, P., Stloukal, E., Hagedorn, G., Wetzel, F., Glöckler, F., Kroupa, A., Korb, G., Hoffmann, A., Häuser, C., Kohlbecker, A., Müller, A., Güntsch, A., Stoev, P. \& Penev, L., 2014: Fauna Europaea - all European animal species on the web. Biodiversity Data Journal 2, 1-35. https://doi. org/10.3897/BDJ.2.e4034

Habeler, H., 2008[2003]: Die Schmetterlinge der Adria-Insel Krk. Eine ökofaunistische Studie. 
JAKšić, P., 2016: Tentative Check List of Serbian Microlepidoptera. Ecologica Montenegrina 7, 33-258.

Jež, M., Kastelic, M. \& Kamin, J., 2015: Spoladea recurvalis (Fabricius, 1775) (Lepidoptera: Crambidae), nova vrsta metulja v Sloveniji. Acta Entomologica Slovenica 23, 135-138.

Leraut, P., 2012: Moths of Europe, Volume 3: Zygaenids, Pyralids 1 and Brachodids. NAP Editions, Verrières-le Buisson. 599 pp.

Lesar, T. \& Govedič, M., 2010: Check List of Slovenian Microlepidoptera. Natura Sloveniae 12(1), 35-125.

Slamka, F., 2006: Pyraloidea of Europe (Lepidoptera) 1. Pyralinae, Galleriinae, Epipaschiinae, Cathariinae \&amp; Odontiinae. František Slamka, Bratislava. 138 pp.

Slamka, F., 2008: Pyraloidea of Europe (Lepidoptera) 2. Crambinae \&amp; Schoenobiinae. František Slamka, Bratislava. 224 pp.

Slamka, F., 2013: Pyraloidea of Europe (Lepidoptera), 3. Pyraustinae \& Spilomelinae. František Slamka, Bratislava. $357 \mathrm{pp}$.

\title{
SAŽETAK
}

\section{Tri vrste moljaca trava (Lepidoptera: Crambidae) novih za faunu Hrvatske}

\author{
T. Koren \& M. Zadravec
}

Fauna noćnih leptira Hrvatske još uvijek nije dovoljno poznata i istražena, što posebno vrijedi za skupine Microlepidoptera, uključujući i moljce trava (Crambidae). Tijekom istraživanja noćnih leptira raznih dijelova Hrvatske zabilježene su tri vrste moljaca trava, nove za faunu Hrvatske. Vrsta Ostrinia quadripunctalis zabilježena je na brdu Krč, nedaleko Zagreba, koje se nalazi u dijelu ekološke mreže Natura 2000 (HR2001298 Vejalnica i Krč) i unutar Značajnog krajobraza Goranec. Radi se o rijetkoj i lokalnoj vrsti, s disjunktnom rasprostranjenošću u Europi. Nastanjuje suhe i termofilne padine, u koje spade i brdo Krč. Preostale dvije vrste, Spoladea recurvalis i Herpetogramma licarsisalis spadaju u migratorne vrste koje nastanjuju tropska i suptropska područja, a zabilježene su na otoku Lokrumu kraj Dubrovnika, koji je zaštićen kao Posebni rezervat šumske vegetacije. Ovakvi prilozi uvelike pomažu i poboljšavaju poznavanje faune Hrvatske te predstavljaju korak ka stvaranju popisa vrsta. 